\title{
The Exploration of Practical Teaching Mode Based on Curriculum Group \\ Jing Chang a
}

Institute of Information Science and Technology South China Business College Guangdong University of Foreign Studies, Guangdong, Guangzhou 510545, China.

a hapipingye@163.com

Keywords: Curriculum group, Practice teaching, Ability enhancement.

\begin{abstract}
According to the construction of curriculum group teaching system for computer major and the talent training mode of cooperation between school and enterprise, this paper probes into the experimental teaching system scheme of course group. This paper introduces the concrete measures for the reform of the practical teaching system in the course group of computers major in south china business college Guangdong university of foreign studies. It has been proved by practice that the main courses are grouped into groups, and the general skills of students such as computer application and software development are improved, and the practical effect is obvious.
\end{abstract}

\section{Introduction}

In order to meet the requirement of cultivating applied talents, the Institute of Information Science and Technology has put forward the construction of curriculum group. The construction of curriculum group project mainly includes the following three aspects: first, in order to adapt to the new educational concept and satisfy the "thick foundation", Second, the number of undergraduate teaching courses is more numerous, the total teaching hours are saturated, the teaching is compact, the theoretical study hours are more, the practical learning hours are less, which leads to the limitation of elective courses in the direction of study hours. Third, the construction of professional courses is mostly confined to a single course, which shows obvious limitations and shortcomings on the level of achieving the goal of talent training. Construction of Curriculum Group projects It has gradually become an important condition for the cultivation of applied talents, and it is also an extremely important basic work in the construction of specialty.

\section{Introduction of Curriculum Group}

The basic idea of curriculum group construction is to build a class of courses which belong to a category of training ability as a course group and break the attribute of curriculum content. To grasp the distribution of curriculum contents from the level of training objectives and implement [1]. The research course construction is beneficial to the implementation of the professional teaching plan and the realization of the training goal.

Aiming at the goal of curriculum group construction, we should plan the knowledge structure and frame system of curriculum group, carry out knowledge point, draw up the plan of linking knowledge points between courses, integrate teaching contents, and grasp the distribution and implementation of curriculum content from the level of training goal. Pay attention to skill training, weaken the concept of curriculum personality, and strengthen the integration, intersection and correlation between curriculum contents. In order to ensure the abundance of teaching resources of curriculum group, to build the website of relevant courses, to build the experimental platform of curriculum group, to study the implementation plan, to compile or revise the teaching material and teaching plan, to ensure the rich teaching resources of the curriculum group. The experiment contents of each course are organically connected according to certain relation [2]. Curriculum group is a dynamic system. It is necessary to make flexible adjustment according to social needs and professional development and explore the construction of curriculum group based on vocational ability [3] and pay attention to the 
cultivation of students' comprehensive quality and practical skills, so that the design of curriculum group can meet the needs of the society.

\section{Current Situation Analysis}

Computer science is a very practical specialty, which not only requires the practitioners to have solid theoretical knowledge, but also requires the practitioners to have a strong ability to apply and practice. There is a certain number of practical teaching in the course of professional teaching and training. Practical teaching means to train students' ability to analyze and solve problems in order to cooperate with theoretical teaching. A teaching link set up to strengthen professional training and exercise students' practical ability. It generally includes basic experiments, course design, internships and graduation projects, or graduation papers. Students in the basic experiment, according to the content of the teaching, Chapters are trained in basic skills. Students can only verify the knowledge of individual chapters, but they cannot master the content of the course as a whole. Moreover, it is difficult to solve the application problem by synthetically using the knowledge learned. The relevant courses of computer major are highly relevant, so it often needs several courses to realize a system. The related courses are arranged in different semesters, which cannot achieve the expected results.

In recent years, with the reform of school teaching, the importance of practical teaching has been paid attention to. Since practice teaching has been regarded as a kind of auxiliary teaching for a long time, in the cultivation of knowledge and ability, emphasis is placed on knowledge; In the cultivation of thinking ability and hands-on ability, emphasis is placed on thinking, which results in the present situation of emphasizing the consolidation of knowledge rather than the cultivation of ability.

\section{Practical Mode Based on Curriculum Group}

According to the training objectives of the three majors in the Institute of Information Science and Technology and the needs of the society for talents, it is necessary to pay attention to the penetration and intersection of knowledge among the courses. The systematic content of experimental teaching can guarantee the integrity and continuity of experimental teaching and help to improve the students' systematic ability. Under the premise of the construction of curriculum group, it is necessary to embody the logic and integrity of the knowledge system. A centralized practice model based on curriculum group is implemented.

\subsection{Curriculum Group Organization Planning}

The course group organization planning is carried out for the main courses of the specialty, and the continuity and application of the courses are fully considered. Table 1 gives a concrete plan [4].

Table 1. Training Project Based on Curriculum Group

\begin{tabular}{|c|c|c|}
\hline Curriculum group & Training project & target \\
\hline Programming foundation & \multirow{4}{*}{ programming capability } & \multirow{4}{*}{$\begin{array}{c}\text { Improving theoretical and programming } \\
\text { capabilities }\end{array}$} \\
\hline data structure & & \\
\hline Object-Oriented Programming & & \\
\hline Java program design & & \\
\hline Database principle & \multirow[b]{2}{*}{ Database application capability } & \multirow{2}{*}{$\begin{array}{l}\text { Implementation of a small Management } \\
\text { Information system based on a specific } \\
\text { platform }\end{array}$} \\
\hline $\begin{array}{l}\text { Advanced database } \\
\text { programming }\end{array}$ & & \\
\hline software engineering & \multirow{2}{*}{$\begin{array}{l}\text { Software analysis, design, } \\
\text { implementation, testing } \\
\text { capability }\end{array}$} & \multirow{2}{*}{$\begin{array}{l}\text { Combining theory with practice to } \\
\text { implement a software system }\end{array}$} \\
\hline $\begin{array}{c}\text { software test } \\
\text { software project management }\end{array}$ & & \\
\hline Electronic circuit technology & \multirow{3}{*}{ Hardware application project } & \multirow{3}{*}{$\begin{array}{c}\text { Analysis, Design and implementation of } \\
\text { computer hardware and embedded } \\
\text { applications }\end{array}$} \\
\hline $\begin{array}{c}\text { Principle and Interface } \\
\text { Technology of Microcomputer }\end{array}$ & & \\
\hline $\begin{array}{c}\text { Embedded system } \\
\text { Principle and Application of } \\
\text { single Chip Microcomputer }\end{array}$ & & \\
\hline
\end{tabular}




\subsection{Curriculum Group Practice System Reform}

(1) Aim at capacity development

According to the talent training plan, from the second semester to the seventh semester, the experiment and practice complement each other, the experiment, the content of the practice are connected with each other, and the level is raised step by step. In this way, the training of practical courses can be serialized and stratified. So as to strengthen the students' practical ability and practice ability [5].

(2) Construction of three-level experiment and practical teaching system

The first level trains the basic theory and the basic operation skill. The content of this level includes the compulsory and elective experimental contents of the curriculum group experiment syllabus. The second level is to cultivate the ability of system design and comprehensive application, which adopts the practice of whole week curriculum design and comprehensive experiment to train the students' comprehensive application ability. The third level: cultivating the practical ability of application development and innovation. The teaching at this level is carried out in the form of enterprise practice training, graduation design, etc., which requires students to assemble the practical projects of enterprises in the off-campus practical teaching base for application development, as shown in figure 1.

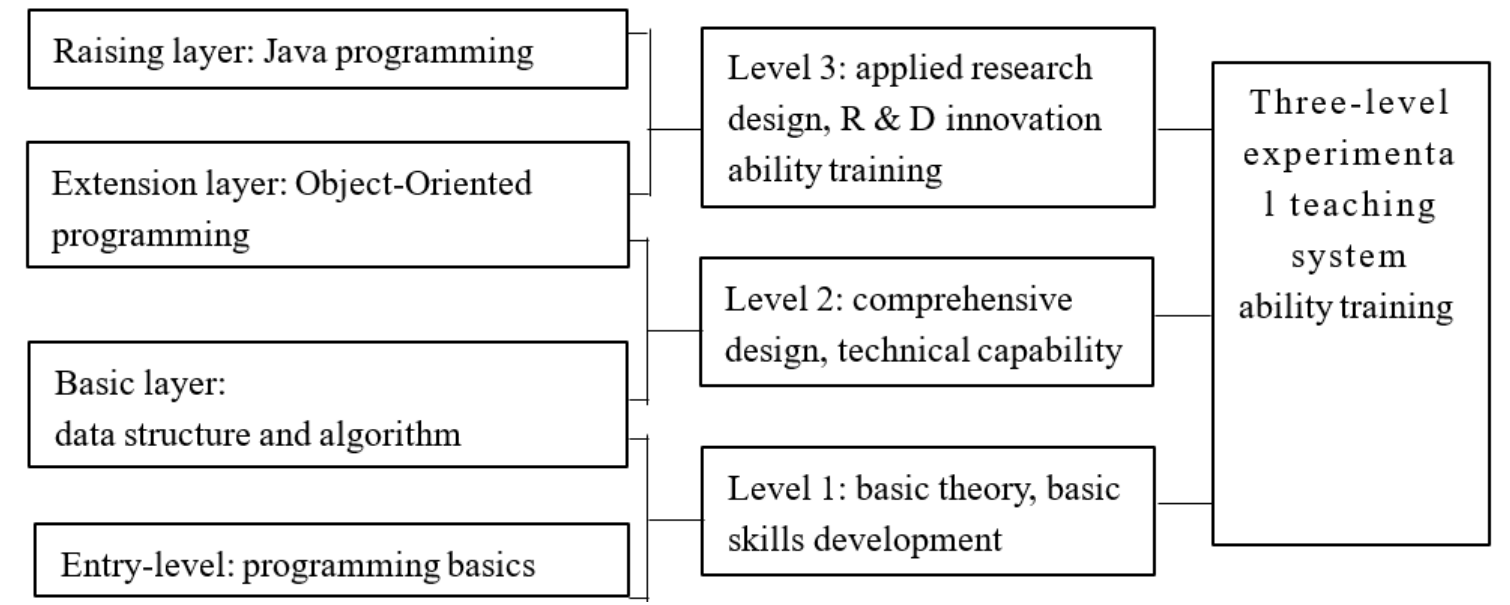

Fig. 1. Diagram of Three-Level Experimental Teaching System

(3) Increase engineering training links

In recent years, the reform of talent training programs has been continuously carried out in recent years and has been revised three times. After a long period of experimental teaching and exploration, students have formed their own characteristics. Students have started to contact the enterprise training projects from the third year of university. If the enterprise teachers take the actual combat projects to carry out a course of practical training for 7 to 10 days at a time, so that students can understand the projects of the enterprise in advance and receive comprehensive professional practice and practical training, they can have a more comprehensive understanding of the actual needs of the project. Master the basic method of design, so as to improve the analysis of problems, comprehensive practical ability.

\section{Conclusion}

Practical teaching is an important link of innovative education in colleges and universities. As an important link in practical teaching, the course design of computer specialty is a practical link to improve the practice on the basis of basic experiment [6]. It has been proved by practice that the students' various skills are generally improved and the practical effect is obvious, which ensures the teaching quality of the practical link by designing and concentrating the practice according to the course group and with strict organization. 


\section{Acknowledgments}

Department of education of Guangdong province 2016 featured innovation projects (education and research development), "Research on training model of applied talents of computer major based on curriculum group and ability-oriented training", project number: 2016GXJK224

The Engineering Project of Teaching quality and Teaching Reform of undergraduate Universities in Guangdong Province in 2015 "South China Business College Guangdong University of Foreign Studies-Guangzhou Xinbao Software Science and Technology Co., Ltd." (Guangdong Education High letter [2015] 133).

\section{References}

[1]. Lu Wei-qun. Principles and Strategies of Curriculum Group Construction in normal Universities [J]. Study on higher Education in Heilongjiang Province,2007(11):110-112.

[2]. Zhang Jing. Research and practice of course Group of computer Science and Technology Specialty [J]. Computer knowledge and Technology,2009(5):25-32.

[3]. Wang Bao-jun. Construction of Curriculum system based on the training of Professional ability [J]. Journal of Zhejiang Institute of Communications and Technology,2008(2):55-58.

[4]. Ye Xuejun. Experimental Teaching Reform of computer hardware course Group [J]. Computer Education,2011(17).

[5]. Wen Liuying, Feng Dan, Wang Shiyuan. Reform of computer hardware experiment [J]. Experimental Science and Technology,2011(01).

[6]. Huang Chuanhe, Huang Jianzhong, Wu Libing. Design of practical Teaching system and method for computer Specialty [J]. Computer Education,2007(22):87-89. 